\title{
Causes of death among street-connected children and youth in Eldoret, Kenya
}

\author{
Lonnie Embleton ${ }^{1}$, David Ayuku' ${ }^{2}$ Dominic Makori ${ }^{3}$, Allan Kamanda ${ }^{3}$ and Paula Braitstein ${ }^{4,5,6,7,8^{*}}$
}

\begin{abstract}
Background: Street-connected young people carry a disproportionate burden of morbidities, and engage in a variety of practices that may heighten their risk of premature mortality, yet there are currently no reports in the literature on the rates or risk factors for mortality among them, nor on their causes of death. In low- and middleincome countries they are frequently in situations that violate their human rights, likely contributing to their increased burden of morbidities and vulnerability to mortality. We thus sought to describe the number of deaths annually, causes of death, and determine the number of deaths attributable to HIV among street-connected young people aged 0 to 30 years in Eldoret, Kenya.

Methods: Eldoret, Kenya has approximately 1900 street-connected young people. We collected data on deaths occurring from October 2009 to December 2016 from Moi Teaching and Referral Hospital records, Academic Model Providing Access to Healthcare HIV program records, and utilized verbal autopsies when no records were available. Descriptive analyses were conducted stratified by sex and age category, and frequencies and proportions were calculated to provide an overview of the decedents. We used logistic regression to assess the association between underlying cause of death and sex, while controlling for age and location of death.

Results: In total there were 100-recorded deaths, 66 among males and 34 among females; 37\% of were among those aged $\leq 18$ years. HIV/AIDS (37\%) was the most common underlying cause of death, followed by assault (36\%) and accidents (10\%) for all decedents. Among males, the majority of deaths were attributable to assault (49\%) and HIV/AIDS (26\%), while females primarily died due to HIV/AIDS (59\%).

Conclusion: Our results demonstrate a high number of deaths due to assault among males and HIV/AIDS among males and females. Our findings demonstrate the need for studies of HIV prevalence and incidence among this population to characterize the burden of HIV, particularly among young women given the higher number of deaths attributed to HIV/AIDS among them. Most deaths were preventable and require the urgent attention of service providers and policymakers to implement programs and services to prevent premature mortality and uphold children's rights.
\end{abstract}

Keywords: Street children and youth, Mortality, HIV, Kenya, Homicide, Assault, children's rights

\section{Background}

In many low- and middle-income countries, the streets play a central role in the lives of children and youth (street-connected young people) [1]. Street-connected young people spend the majority of their days or days and nights on the streets in public places, generating livelihoods, and living in precarious inadequate

\footnotetext{
* Correspondence: pbraitstein@gmail.com

${ }^{4}$ College of Health Sciences, School of Medicine, Department of Medicine, Moi University, Eldoret, Kenya

${ }^{5}$ Dalla Lana School of Public Health, University of Toronto, Toronto, Canada Full list of author information is available at the end of the article
}

conditions with a lack of protection. Young people turn to the streets for survival, as a result of enduring poverty, abuse, and family conflict at home [2]. Once on the streets, these young people are highly marginalized, subject to numerous human rights violations [3-5], and carry a disproportionate burden of morbidities in the areas of substance use [6], infectious diseases, mental health, sexual and reproductive health $[7,8]$. They frequently experience violence and abuse on the streets, which is perpetrated by peers, family, other adults, and police [7]. All of these factors may heighten their risk of

(c) The Author(s). 2018 Open Access This article is distributed under the terms of the Creative Commons Attribution 4.0 International License (http://creativecommons.org/licenses/by/4.0/), which permits unrestricted use, distribution, and reproduction in any medium, provided you give appropriate credit to the original author(s) and the source, provide a link to the Creative Commons license, and indicate if changes were made. The Creative Commons Public Domain Dedication waiver (http://creativecommons.org/publicdomain/zero/1.0/) applies to the data made available in this article, unless otherwise stated. 
death, yet there are currently no reports in the literature on the rates or risk factors for mortality among streetconnected children and youth in low- and middleincome countries, nor on their causes of death [7].

Recently, the UN Office of the High Commissioner Human Rights (UNOHCR) has drafted a General Comment on children in street situations, recognizing their unique circumstances and the need to ensure the Convention on the Rights of the Child (CRC) is adequately protecting street-connected children and youth. The CRC outlines the basic human rights children are entitled to including: non-discrimination; the right to survival; to reach their full potential; to protection from all forms of abuse, neglect, and exploitation; and to participate fully in matters affecting their social, economic, religious, cultural and political life [9]. The UNOHCR identified five key articles of the CRC in relation to children in street situations for the General Comment including: Article 2.1, States Parties shall respect and ensure the rights set forth in the present Convention to each child within their jurisdiction without discrimination of any kind, irrespective of the child's or his or her parent's or legal guardian's race, colour, sex, language, religion, political or other opinion, national, ethnic or social origin, property, disability, birth or other status; Article 6, States Parties recognize that every child has the inherent right to life and shall ensure to the maximum extent possible the survival and development of the child; Article 15, States Parties recognize the rights of the child to freedom of association and to freedom of peaceful assembly; Article 20, A child temporarily or permanently deprived of his or her family environment, or in whose own best interests cannot be allowed to remain in that environment, shall be entitled to special protection and assistance provided by the State. States Parties shall in accordance with their national laws ensure alternative care for such a child; Article 27, States Parties recognize the right of every child to a standard of living adequate for the child's physical, mental, spiritual, moral and social development [10]. Street-connected young people in low- and middle-income countries are frequently in situations that violate these basic human rights [3-5, 11, 12], likely contributing to their increased burden of morbidities and vulnerability to mortality, which is undoubtedly avoidable in many circumstances.

In North America, homeless youth sustain significantly higher rates of mortality in comparison to their peers in the general population [13-15]. In Canada, Roy et al. found that a cohort of homeless youth had a mortality rate which was 11 times higher than the observed rate among youth nationally [13]. In a subsequent cohort they found mortality decreased substantially after the introduction of housing and social services [14], in alignment with CRC Article 20 and 27, ensuring children and youth have special protection and an adequate standard of living [9]. Most recently, Auerswald [15], found that homeless youth in San Francisco had a mortality rate 10 times that of the general population. The most common causes of death among homeless youth in these studies were suicide and drug-related [13-15]. In Canada, HIV infection was a significant predictor of mortality for street youth [13]. Homeless young people in North America have documented higher rates of HIV in comparison to the general adolescent [16-20] largely due to injection drug use [21-23]. As street-connected children and youth in low- and middle-income countries primarily use volatile solvents, with little to no injection drug use [6], little attention has been paid to their burden of HIV or mortality, despite often living in HIV endemic settings, engaging in high risk sexual practices [24-27], and having numerous morbidities [7].

It is vital to understand street-connected young people's causes of death and the burden of HIV among them in low- and middle-income countries if deaths are to be prevented and policy and services designed to assist them in accord with the CRC. We thus sought to describe the number of deaths annually, causes of those deaths, and determine the number of deaths attributable to HIV among street-connected young people aged 0-30 in Eldoret, Kenya from October 2009 to December 2016. We chose to expand our definition of young people from the UN definition for 'youth' aged 15 to 24 years [28] to encompass children and youth aged 0 to 30 years given the difficulty confirming age in this population in a resource-constrained setting. We also explored differences in causes of death by sex and age group. This study will provide the first report in the literature concerning mortality among street-connected young people in low- and middle-income settings and illuminate the burden of disease among street-connected young people in Eldoret, Kenya.

\section{Methods \\ Study setting}

Uasin Gishu (UG) County is located $375 \mathrm{~km}$ northwest of Kenya's capital, Nairobi. In 2010, UG County had a population of 894,179 , of whom $41.5 \%$ were aged 14 years or less. Approximately $51.3 \%$ of the UG County population lives below the Kenyan poverty line. Eldoret town is the administrative capital of UG County and from the 2009 census, had a population of 289,389 [29]. Eldoret is home to Moi University, Moi Teaching and Referral Hospital (MTRH), and the Academic Model Providing Access to Healthcare (AMPATH) [30]. AMPATH was initiated in 2001 as a partnership between MTRH (Kenya's second referral hospital. A referral hospital refers to a National hospital that has specialized care.), Moi University School of Medicine, 
and a consortium of universities from North American led by Indiana University. AMPATH began as an HIV care and treatment program, and with support from PEPFAR currently has over 80,000 HIV infected patients in care across a swathe of western Kenya. The MTRH mortuary serves UG County, and deaths that occur outside of hospital are typically brought to MTRH mortuary.

\section{Study population}

Street-connected young people were defined as individuals aged 0 to $\leq 30$ years who either a) were spending both days and nights on the streets, and had limited-tono parental/guardian contact or b) were spending a portion or majority of their time on the street and had a parent/guardian/caregiver to whom they returned at night. In 2016, there were 1903 individuals counted who were connected to the streets, including 1151 aged less than or equal to 24 years, and 766 aged less than or equal to 18 years in Eldoret as documented through a point-in-time count; of whom $75 \%$ were male and $25 \%$ were female [31]. It is believed there are between 1000 and 3000 street-connected people in and around Eldoret at any time and that this number varies with seasonal changes and migration patterns in this highly mobile population.

\section{Sources of data}

A community advocate with an in-depth knowledge of Eldoret's street-connected young people informally documented deaths and conducted unstandardized verbal autopsies from October 2009 to May 2013 and brought this data to our research team. Deaths involving streetconnected young people in Eldoret are brought to the attention of the community advocate by barrack leaders (leaders of groups of street youth) or street-connected young people themselves, as they seek his assistance in navigating the burial process for the deceased individuals. In most cases, for deaths that have occurred outside the hospital, at the barracks or in the streets, the community advocate liaises with the police department to transport the deceased to the hospital mortuary. The community advocate's documentation was provided to the research team and it supplied the names of deceased street-connected young people from October 2009 May 2013. Completeness of the data from 2009 to 2013 provided by the community advocate may be limited given the unstandardized documentation, however, given the community advocate's integral role in liaising with the MTRH mortuary, police, and street-connected young people to facilitate autopsies and burials, it is likely the data is reliable and accurate, yet this documentation may have missed deaths that were not reported to the advocate. We sought to retrospectively ascertain detailed data on the documented deaths by using the names, age, sex, and documented cause of death of the deceased provided by the advocate. We searched MTRH mortuary and hospital records to ascertain cause of death for all in and out of hospital deaths from October 2009 to May 2013.

From May 2013 to December 2016 we prospectively collected mortality data and introduced standardized mortality data collection forms (for infants $<1$ year and street-connected young people $>1$ year) for the community advocate to use to conduct verbal autopsies and retrieve data from the mortuary and hospital records at MTRH. Data collected from the standardized mortality forms included: date of death, name, age, sex, status on the streets, barracks, location of death (in or out of hospital), autopsy performed (yes versus no), circumstances of death, immediate cause of death, underlying cause of death, cause of death data source, history of previously known medical conditions, and history of injuries and accidents. Cause of death was determined based on an account of the circumstances of death and a cause given by next of kin, friends, or barracks leaders when the decedent did not pass through MTRH mortuary. In cases where the community advocate was liaising with the MTRH mortuary, the circumstance of death, immediate cause of death, and underlying cause of death was documented by the advocate from mortuary records from 2013 onwards when possible.

Retrospective and prospective data were compiled into a database and immediate and underlying causes of death were coded as ascertained from MTRH mortuary certificate for cause of death. When no formal records were located, the cause of death reported in this analysis was based on informal verbal autopsies performed by the community advocate in his documentation. Assault was defined as any intentional physical attack sustained by the decedent and may have been the result of mob justice or homicide. Mob justice was defined as punishment enacted by citizens outside of the legal system, on an individual whom a mob claims perpetrated a crime [32]. Mob justice typically results in a violent attack or assault causing bodily harm on the accused as punishment or retribution for a crime. Accidental deaths were defined as unintentional injuries, and included road traffic accidents, drowning, and other accidents. For all deaths from October 2009 to December 2016, AMPATH records were searched to determine the HIV status of the deceased, if they were in care, and on treatment.

\section{Ethics}

Moi University School of Medicine and MTRH Institutional Research Ethics Committee (IREC) approved this study. The community advocate obtained verbal consent from persons providing verbal autopsy information. 
IREC approved the use of verbal autopsy data collected, and the extraction of hospital, mortuary and other relevant data to help ascertain cause of death.

\section{Analysis}

Descriptive analyses were conducted and frequencies and proportions were calculated to provide an overview of the decedents. We used logistic regression to assess the association between underlying cause of death and sex, while controlling for age and location of death. The statistical program $\mathrm{R}$ was used for analysis.

\section{Results}

From October 2009 to December 2016, there were 100recorded deaths among street-connected young people; with $37 \%$ of deaths occurring among youth aged $\leq 18$ years ( $16 \%$ among children $<13$ years), $66 \%$ occurring among males and $34 \%$ among females. The median age of decedents was 22 years (IQR: 15-25). Figure 1 demonstrates the number of deaths over time stratified by sex, and shows an increase in recorded deaths with the introduction of standardized mortality data collection from 2013 onwards. Deaths occurred in (38\%) and out $(48 \%)$ of hospital, but more frequently in hospital (56\%) for females and out of hospital for males (58\%). Less than half $(32 \%)$ of all decedents had an autopsy. In $70 \%$ of cases, immediate and underlying cause of death was established through mortuary and hospital records, with the remaining ascertained through verbal autopsy. Table 1 summarizes the immediate causes of death and Table 2 summarizes the underlying cause of death stratified by sex and age for street-connected young people. Most commonly, HIV/AIDS (37\%) was the underlying cause of death, followed by assault (36\%) and accidents $(10 \%)$ for all decedents. Assault was attributed to mob justice in $42 \%$ of assault-related deaths that provided details regarding circumstances of death. Among males, the majority of deaths were attributable to assault (49\%) and HIV/AIDS (25.8\%), while females primarily died due to HIV/AIDS (59\%). For decedents aged 18 years or less, assault accounted for $30 \%$ of deaths, and the proportion of those that died due to HIV/AIDS was similar between those aged 18 years or less or over 18 .

In total, 37 street-connected young people died due to HIV/AIDS. A total of 22 (59\%) had an AMPATH identifying number (meaning that they had at least registered in the AMPATH program), and 16 (43\%) had an initial clinical encounter. Of those that had enrolled and had an initial encounter, 7 were in care at their time of death, and 9 were considered lost to follow-up and had not had a clinical encounter within 6 months of their documented date of death. Males were significantly less likely to die due to HIV/AIDS (OR $=0.2495 \%$ CI: $0.10-0.58$ ) in comparison to females, but were significantly more likely to succumb to death due to assault $(\mathrm{OR}=7.06,95 \% \mathrm{CI}$ : 2.45-25.76). In adjusted analyses controlling for age and location of death these associations remained (HIV/ AIDS AOR $=0.18$ 96\%CI: 0.06-0.49, Assault AOR $=5$. 45, 95\%CI: $1.75-20.97)$.

\section{Discussion}

Our results demonstrate a high number of deaths due to assault among males and HIV/AIDS among males and females. These results suggest that street-connected young people are extremely vulnerable to preventable causes of death. Our findings on mortality among street-

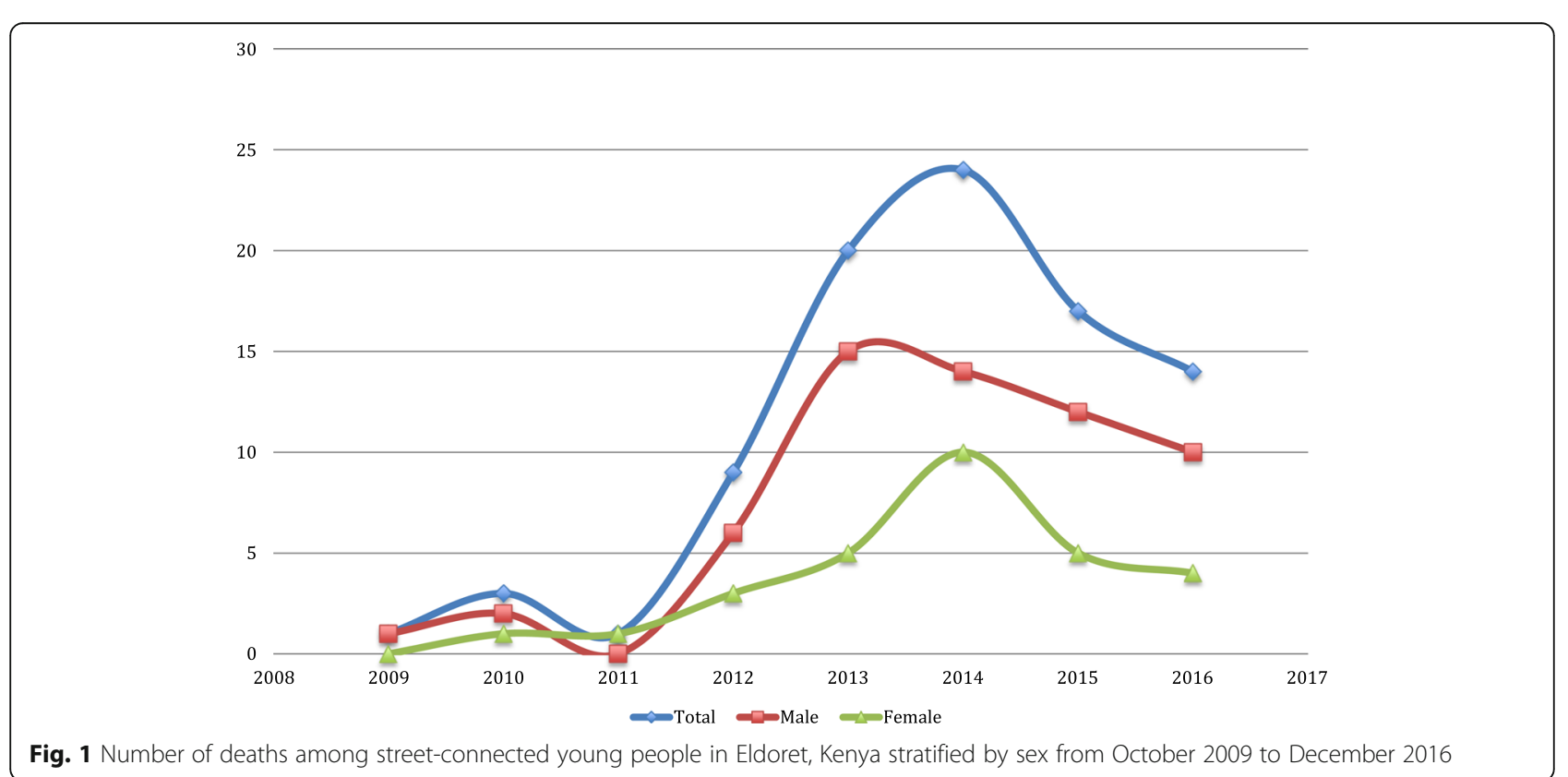


Table 1 Immediate cause of death by sex and age among street-connected young people in Eldoret Kenya 2009-2016

\begin{tabular}{|c|c|c|c|c|c|c|c|c|c|c|}
\hline \multirow{2}{*}{$\begin{array}{l}\text { Immediate Cause } \\
\text { of death }\end{array}$} & \multicolumn{2}{|l|}{ All } & \multicolumn{2}{|l|}{ Males } & \multicolumn{2}{|c|}{ Females } & \multicolumn{2}{|c|}{$\leq 18$ years of age } & \multicolumn{2}{|c|}{$>18$ years of age } \\
\hline & $N=100$ & $\%$ & $n=66$ & $\%$ & $n=34$ & $\%$ & $n=37$ & $\%$ & $n=60$ & $\%$ \\
\hline Blunt Force Trauma & 28 & $28.0 \%$ & 27 & $40.9 \%$ & 1 & $2.9 \%$ & 7 & $18.9 \%$ & 20 & $33.3 \%$ \\
\hline Tuberculosis & 19 & $19.0 \%$ & 8 & $12.1 \%$ & 11 & $32.4 \%$ & 7 & $18.9 \%$ & 12 & $20.0 \%$ \\
\hline Asphyxia & 10 & $10.0 \%$ & 9 & $13.6 \%$ & 1 & $2.9 \%$ & 5 & $13.5 \%$ & 5 & $8.3 \%$ \\
\hline HIV/AIDS & 7 & $7.0 \%$ & 3 & $4.5 \%$ & 4 & $11.8 \%$ & 4 & $10.8 \%$ & 3 & $5.0 \%$ \\
\hline Pneumonia & 5 & $5.0 \%$ & 3 & $4.5 \%$ & 2 & $5.9 \%$ & 3 & $8.1 \%$ & 1 & $1.7 \%$ \\
\hline Meningitis & 4 & $4.0 \%$ & 3 & $4.5 \%$ & 1 & $2.9 \%$ & 1 & $2.7 \%$ & 3 & $5.0 \%$ \\
\hline Infanticide & 3 & $3.0 \%$ & 0 & $0.0 \%$ & 3 & $8.8 \%$ & 3 & $8.1 \%$ & 0 & $0.0 \%$ \\
\hline Cardiovascular & 3 & $3.0 \%$ & 1 & $1.5 \%$ & 2 & $5.9 \%$ & 0 & $0.0 \%$ & 3 & $5.0 \%$ \\
\hline Diabetes Related & 3 & $3.0 \%$ & 1 & $1.5 \%$ & 2 & $5.9 \%$ & 0 & $0.0 \%$ & 3 & $5.0 \%$ \\
\hline Gun shot wound & 2 & $2.0 \%$ & 2 & $3.0 \%$ & 0 & $0.0 \%$ & 1 & $2.7 \%$ & 1 & $1.7 \%$ \\
\hline Drug Related & 2 & $2.0 \%$ & 2 & $3.0 \%$ & 0 & $0.0 \%$ & 0 & $0.0 \%$ & 2 & $3.3 \%$ \\
\hline Kidney Failure & 2 & $2.0 \%$ & 1 & $1.5 \%$ & 1 & $2.9 \%$ & 1 & $2.7 \%$ & 1 & $1.7 \%$ \\
\hline Anaphylaxis & 1 & $1.0 \%$ & 1 & $1.5 \%$ & 0 & $0.0 \%$ & 0 & $0.0 \%$ & 1 & $1.7 \%$ \\
\hline Anemia & 1 & $1.0 \%$ & 0 & $0.0 \%$ & 1 & $2.9 \%$ & 1 & $2.7 \%$ & 0 & $0.0 \%$ \\
\hline Burns & 1 & $1.0 \%$ & 1 & $1.5 \%$ & 0 & $0.0 \%$ & 0 & $0.0 \%$ & 1 & $1.7 \%$ \\
\hline Cerebral Palsy & 1 & $1.0 \%$ & 0 & $0.0 \%$ & 1 & $2.9 \%$ & 1 & $2.7 \%$ & 0 & $0.0 \%$ \\
\hline Cervical Cancer & 1 & $1.0 \%$ & 0 & $0.0 \%$ & 1 & $2.9 \%$ & 0 & $0.0 \%$ & 1 & $1.7 \%$ \\
\hline Fetal Alcohol Syndrome & 1 & $1.0 \%$ & 0 & $0.0 \%$ & 1 & $2.9 \%$ & 1 & $2.7 \%$ & 0 & $0.0 \%$ \\
\hline Gl bleeding & 1 & $1.0 \%$ & 1 & $1.5 \%$ & 0 & $0.0 \%$ & 0 & $0.0 \%$ & 1 & $1.7 \%$ \\
\hline Liver Cirrhosis & 1 & $1.0 \%$ & 1 & $1.5 \%$ & 0 & $0.0 \%$ & 0 & $0.0 \%$ & 0 & $0.0 \%$ \\
\hline Neonatal Sepsis & 1 & $1.0 \%$ & 0 & $0.0 \%$ & 1 & $2.9 \%$ & 1 & $2.7 \%$ & 0 & $0.0 \%$ \\
\hline Premature baby & 1 & $1.0 \%$ & 0 & $0.0 \%$ & 1 & $2.9 \%$ & 1 & $2.7 \%$ & 0 & $0.0 \%$ \\
\hline Septicaemia & 1 & $1.0 \%$ & 1 & $1.5 \%$ & 0 & $0.0 \%$ & 0 & $0.0 \%$ & 1 & $1.7 \%$ \\
\hline Other Traumatic Injury & 1 & $1.0 \%$ & 1 & $1.5 \%$ & 0 & $0.0 \%$ & 0 & $0.0 \%$ & 1 & $1.7 \%$ \\
\hline
\end{tabular}

connected young people reveal a similar distribution of causes of death to those reported on adolescents in western Kenya, with females succumbing to death due to infectious diseases and males due to injuries [33]. Assault and accidental deaths attributed to almost half of all deaths among street-connected young people, almost exclusively among males and this is significantly higher than reported in community-based adolescents in western Kenya [33] and homeless youth in North America $[13,15]$. This high level of homicide is reflective of the

Table 2 Underlying cause of death by age and sex among street-connected young people in Eldoret Kenya 2009-2016

\begin{tabular}{|c|c|c|c|c|c|c|c|c|c|c|}
\hline \multirow{2}{*}{$\begin{array}{l}\text { Underlying Cause } \\
\text { of death }\end{array}$} & \multicolumn{2}{|l|}{ All } & \multicolumn{2}{|l|}{ Males } & \multicolumn{2}{|c|}{ Females } & \multicolumn{2}{|c|}{$\leq 18$ years of age } & \multicolumn{2}{|c|}{$>18$ years of age } \\
\hline & $N=100$ & $\%$ & $n=66$ & $\%$ & $n=34$ & $\%$ & $n=37$ & $\%$ & $n=60$ & $\%$ \\
\hline HIV/AIDS & 37 & $37.0 \%$ & 17 & $25.8 \%$ & 20 & $58.8 \%$ & 13 & $35.1 \%$ & 23 & $38.3 \%$ \\
\hline Assault & 36 & $36.0 \%$ & 32 & $48.5 \%$ & 4 & $11.8 \%$ & 11 & $29.7 \%$ & 24 & $40.0 \%$ \\
\hline Accidental & 10 & $10.0 \%$ & 9 & $13.6 \%$ & 1 & $2.9 \%$ & 4 & $10.8 \%$ & 6 & $10.0 \%$ \\
\hline None Reported & 8 & $8.0 \%$ & 5 & $7.6 \%$ & 3 & $8.8 \%$ & 3 & $8.1 \%$ & 4 & $6.7 \%$ \\
\hline Premature baby & 2 & $2.0 \%$ & 1 & $1.5 \%$ & 1 & $2.9 \%$ & 2 & $5.4 \%$ & 0 & $0.0 \%$ \\
\hline Diabetes & 2 & $2.0 \%$ & 0 & $0.0 \%$ & 2 & $5.9 \%$ & 0 & $0.0 \%$ & 2 & $3.3 \%$ \\
\hline Pneumonia & 2 & $2.0 \%$ & 1 & $1.5 \%$ & 1 & $2.9 \%$ & 2 & $2.7 \%$ & 0 & $0.0 \%$ \\
\hline Fetal Alcohol Syndrome & 1 & $1.0 \%$ & 0 & $0.0 \%$ & 1 & $2.9 \%$ & 1 & $2.7 \%$ & 0 & $0.0 \%$ \\
\hline Cerebral Palsy & 1 & $1.0 \%$ & 0 & $0.0 \%$ & 1 & $2.9 \%$ & 1 & $0.0 \%$ & 0 & $0.0 \%$ \\
\hline Meningitis & 1 & $1.0 \%$ & 1 & $1.5 \%$ & 0 & $0.0 \%$ & 0 & $5.4 \%$ & 1 & $1.7 \%$ \\
\hline
\end{tabular}


reported violence sustained by street-connected young people in Africa [34-37], human rights violations, and lack of policy to protect children and youth in street circumstances $[3-5,12]$. Notably, we identified that a large proportion of assault-related deaths among streetconnected young people were attributed to mob justice. Mob justice in Kenya is extra-legal punishment enacted by citizens on an individual whom they claim perpetrated a crime in light of a dysfunctional traditional legal system [32]. Due to street-connected young people's marginalization and discrimination as juvenile delinquents $[3,4,38]$, it is likely that in many cases they may be targeted as the perpetrators' of a crime they did not commit, highlighting the need to uphold street children's rights to protection from harm and non-discrimination. Moreover, there is extensive documentation in Kenya regarding the maltreatment of street-connected young people by Kenyan authorities resulting in bodily harm and death [4, 39-41]. Local media reported that streetconnected children and youth were being forcibly removed by UG county officials and left in neighbouring western counties [39], with a lack of regard for their rights, and provision of protection and care of children as outlined in the Kenya Children's Act [42], leaving them highly vulnerable. Most recently, international media described the phenomenon of cleaning and clearing the streets of children in UG County and raids that led to the death of several street-connected young people in Eldoret [41].

This study demonstrates that systematic studies of HIV prevalence and incidence among this population are urgently needed to accurately assess the burden of HIV among street-connected young people living in HIV endemic settings. Our preliminary findings should be interpreted with caution, but they suggest a potentially hidden epidemic of HIV among street-connected young people in Eldoret and may indicate a low uptake of and retention in care after testing HIV-positive. Preliminary estimates suggest 4-6\% prevalence among streetconnected young people in western Kenya [25, 43], exceeding the National prevalence among youth 15-24 (2.1\%) [44], and the prevalence found among young people in western Kenya [45]. In this study, the majority of deceased street-connected young people who were HIV-positive did not enroll in care at AMPATH or did not return for care after an initial visit. This highlights the need to develop approaches to strengthen linkage and retention in care for marginalized adolescents who are testing HIV-positive in this region. The limited number of young people enrolling and being retained in care may be reflective of the numerous barriers to adolescent sexual and reproductive healthcare in Kenya that have been documented [46-48]. Children in street circumstances have the right to health and access healthcare
(CRC Article 24), and our findings suggest there may be significant barriers to accessing care given the low uptake of registration and retention in care for HIV positive decedents. Given street-connected young people's socioeconomic marginalization [49], substance use [50, 51], and sexual risk practices $[25,27,35,52]$ in our setting, HIV care and treatment programs will likely need to be specially tailored to respond to the population's needs.

This study has several limitations. First, the accuracy of the community advocate's recorded death data from October 2009-May 2013 may be limited, and it is highly probable that deaths occurred that were not recorded. Second, the data was ascertained from a relatively small geographic region of Kenya and therefore may not be representative of street-connected young people throughout the country. Third, cause of death may have been erroneously reported through informal verbal autopsies and we were unable to ascertain data on who provided the cause of death data to the community advocate. We could not assess the accuracy of the information ascertained in the verbal autopsy or if it was collected in a standardized manner prior to 2013. However, due to the relationship the community advocate has with the street-connected young people, it is likely he ascertained relatively accurate data on cause of death due to the trust and respect they place in this individual. It is possible that in some cases the information ascertained may be inaccurate if the person providing data had misinformation regarding the deceased individual. Fourth, individuals who died out of hospital that were not brought to MTRH mortuary had no official record of death. Fifth, In some cases it is likely we missed cases in the morgue master registry as streetconnected children and youth are often documented as "unidentified African male/female" and if no one claims the deceased they are disposed of with little documentation remaining concerning their death. It was impossible in some cases to match the documentation in the morgue records to the documentation provided by the community advocate due to these limitations. Sixth, the results concerning HIV as a cause of death reported from informal verbal autopsies should be interpreted with caution. Lastly, in some cases records were missing, incomplete, or illegible due to the nature of record keeping in a public facility in a highly resource-constrained setting. In light of these limitations, there is a need to improve the capacity of public healthcare facilities to improve documentation and to ensure that children and youth have a right to identity including registration at birth, name and family relations as per the Convention on the Rights of the Child [9].

\section{Conclusion}

In conclusion, most deaths among street-connected young people are preventable and require the urgent attention of service providers and policymakers to 
implement programs and services to prevent premature mortality. Particular attention should be given to designing HIV treatment programs for children and youth in street circumstances to improve their linkage and retention in care. With a large proportion of young people in street circumstances dying due to assault, child protection systems and specific policy to protect and uphold the rights of street-connected young people is urgently needed.

\section{Abbreviations}

AMPATH: Academic Model Providing Access to Healthcare; CRC: Convention on the Rights of the Child; MTRH: Moi Teaching and Referral Hospital; UG: Uasin Gishu; UNOHCR: UN Office of the High Commissioner Human Rights

\section{Acknowledgements}

We would like to acknowledge the street children and youth in Eldoret and their on-going struggle on the streets and thank them for their on-going support and participation in our research activities. We also acknowledge MTRH mortuary and health records staff, especially Solomon Cheruiyot Rop for his assistance in locating records.

\section{Funding}

This work was supported in part by Award Number R01HD060478 from the Eunice Kennedy Shriver National Institute of Child Health and Human Development. The content is solely the responsibility of the authors and does not necessarily represent the official views of the Eunice Kennedy Shriver National Institute of Child Health and Human Development or the National Institutes of Health. This work was also supported by the Canadian Institutes for Health Research through an Applied Public Health Chair to Dr. Braitstein.

\section{Availability of data and materials}

The datasets generated and/or analysed during the current study are not publicly available due privacy and confidentiality reasons and but are available from the corresponding author on reasonable request.

\section{Authors' contributions}

$L E, D A$, and $P B$ designed the study. $A K, D A, L E$, and $D M$ collected the data. LE analyzed the data and led writing the manuscript with PB. All authors read and approved the final manuscript.

\section{Ethics approval and consent to participate}

Moi University School of Medicine and MTRH Institutional Research Ethics Committee (IREC) approved this study. The community advocate obtained verbal consent from persons providing verbal autopsy information. IREC approved the use of verbal autopsy data collected, and the extraction of hospital, mortuary and other relevant data to help ascertain cause of death

\section{Competing interests}

The authors declare that they have no competing interests.

\section{Publisher's Note}

Springer Nature remains neutral with regard to jurisdictional claims in published maps and institutional affiliations.

\footnotetext{
Author details

'Institute of Medical Science, University of Toronto, Toronto, Canada. ${ }^{2}$ College of Health Sciences, School of Medicine, Department of Behavioral Sciences, Moi University, Eldoret, Kenya. ${ }^{3}$ Moi Teaching and Referral Hospital, Eldoret, Kenya. ${ }^{4}$ College of Health Sciences, School of Medicine, Department of Medicine, Moi University, Eldoret, Kenya. ${ }^{5}$ Dalla Lana School of Public Health, University of Toronto, Toronto, Canada. ${ }^{6}$ Regenstrief Institute Inc, Indianapolis, USA. 'Fairbanks School of Public Health, Indiana University, Indianapolis, USA. ${ }^{8}$ Division of Epidemiology, 155 College Street, Toronto, ON M5T 3M, Canada.
}

Received: 10 April 2017 Accepted: 7 May 2018

Published online: 15 May 2018

\section{References}

1. UNOHCHR. Protection and promotion of the rights of children working and/or living on the street. Geneva: UNOHCHR; 2012.

2. Embleton L, Lee H, Gunn J, Ayuku D, Braitstein P. Causes of child and youth homelessness in developed and developing countries: a systematic review and meta-analysis. JAMA Pediatr. 2016;170(5):435-44.

3. Human Rights W. "Where do you want us to go?": abuses against street children in Uganda. 2014.

4. Human Rights Watch. JUVENILE INJUSTICE: Police abuse and detention of street children in Kenya. Kenya: Nairobi; 1997.

5. Human Rights W. What future? Street children in the Democratic Republic of Congo. New York: Human Rights Watch; 2006. Available from: http://hrw. org/reports/2006/drc0406/drc0406webwcover.pdf; http://hrw.org/french/ reports/2006/drc0406/

6. Embleton L, Mwangi A, Vreeman R, Ayuku D, Braitstein P. The epidemiology of substance use among street children in resource-constrained settings: a systematic review and meta-analysis. Addiction. 2013;108:1722-33. Available from: http://www.ncbi.nlm.nih.gov/pubmed/23844822.

7. Woan J, Lin J, Auerswald C. The health status of street children and youth in low- and middle-income countries: a systematic review of the literature. J Adolesc Health. 2013;53:314-21. Available from: http://www.ncbi.nlm.nih. gov/pubmed/23706729.

8. Atwoli L, Ayuku D, Hogan J, Koech J, Vreeman RC, Ayaya S, et al. Impact of Domestic Care Environment on Trauma and Posttraumatic Stress Disorder among Orphans in Western Kenya. PLoS One. 2014;9:e89937. Available from: http://www.ncbi.nlm.nih.gov/pubmed/24625395.

9. UN. Convention On the rights of the child. Geneva: United Nations Office of the high commissioner for Human Rights; 1990.

10. UNOHCHR. OUTLINE: UN Committee on The Rights of the Child, General Comment on children in street situations. 2016. Available from: http://www. ohchr.org/EN/HRBodies/CRC/Pages/ChildrenInStreetSituations.aspx.

11. Human Rights W. Children of the dust. Abuse of Hanoi street children in detention. New York: Human Rights Watch; 2006. Available from: http://hrw. org/reports/2006/vietnam1106/vietnam1106web.pdf.

12. Human Rights W. Swept away. Street children illegally detained in Kigali, Rwanda. New York: Human Rights Watch; 2006. Available from: http://hrw. org/french/backgrounder/2006/rwanda0506/rwanda0506fr.pdf.

13. Roy E, Haley N, Leclerc P, Sochanski B, Boudreau JF, Boivin JF. Mortality in a cohort of street youth in Montreal. JAMA. 2004;292:569-74. Available from: http://www.ncbi.nlm.nih.gov/entrez/query.fcgi?cmd=Retrieve\&db= PubMed\&dopt=Citation\&list_uids $=15292082$.

14. Roy E, Haley N, Boudreau JF, Leclerc P, Boivin JF. The challenge of understanding mortality changes among street youth. J Urban Heal. 2010; 87, 95:-101. Available from: http://www.ncbi.nlm.nih.gov/entrez/query. fcgi?cmd=Retrieve\&db=PubMed\&dopt=Citation\&list_uids=20039140.

15. Auerswald C, Lin J, Parriott A. Six-year mortality in a street-recruited cohort of homeless youth in San Francisco, California. Peer J. 2016;4

16. Marshall BDL, Kerr T, Livingstone C, Li K, Montaner JSG, Wood E. High prevalence of HIV infection among homeless and street-involved Aboriginal youth in a Canadian setting. Harm Reduct J. 2008:5.

17. Roy E, Haley N, Leclerc P, Cedras L, Weber AE. HIV incidence among street youth in Montreal, Canada. AIDS. 2003;17:1071-5.

18. Roy E, Haley N, Leclerc P, Lemire N, Boivin JF, Frappier JY, et al. Prevalence of HIV infection and risk behaviours among Montreal street youth. Int J STD AIDS. 2000:11:241-7.

19. DeMatteo D, Major C, Block B, Coates R, Fearon M, Goldberg E, et al. Toronto street youth and HIV/AIDS: prevalence, demographics, and risks 25: 358-366.

20. Pfeifer RW, Oliver J. A study of HIV seroprevalence in a group of homeless youth in Hollywood, California. J Adolesc Health. 1997;20:339-42.

21. Kerr T, Marshall BDL, Miller C, Shannon K, Zhang R, Montaner JSG, et al. Injection drug use among street-involved youth in a Canadian setting. BMC Public Health. 2009;9:171.

22. Weber AE, Boivin J-F, Blais L, Haley N, Roy E. HIV risk profile and prostitution among female street youths. 4th ed: United States, Joint Departments of Epidemiology and Biostatistics and Occupational Health, McGill University, Montreal, Canada; 2002. p. 525-35. 
23. Gleghorn AA, Marx R, Vittinghoff E, Katz MH. Association between drug use patterns and HIV risks among homeless, runaway, and street youth in northern California. Drug Alcohol Depend. 1998;51:219-27.

24. de Carvalho FT, Neiva-Silva L, Ramos MC, Evans J, Koller SH, Piccinini CA et al. Sexual and drug use risk behaviors among children and youth in street circumstances in Porto Alegre, Brazil. AIDS Behav. 2006;10:S57-66. Available from: http://www.ncbi.nlm.nih.gov/entrez/query.fcgi?cmd= Retrieve\&db=PubMed\&dopt=Citation\&list_uids=16845605.

25. Winston SE, Chirchir AK, Muthoni LN, Ayuku D, Koech J, Nyandiko W, et al. Prevalence of sexually transmitted infections including HIV in street involved adolescents in western Kenya. Sex Transm Infect. 2015;91:305

26. Wutoh AK, Kumoji EK, Xue Z, Campusano G, Wutoh RD, Ofosu JR. HIV knowledge and sexual risk behaviors of street children in Takoradi, Ghana. 2nd ed. USA: United States: School of Pharmacy, Center for Minority Health Services Research, Howard University, 2300 4th Street NW, Washington, DC 20059; 2006. p. 209-15. awutoh@howard.edu.

27. Embleton L, Wachira J, Kamanda A, Naanyu V, Winston S, Ayuku D, et al. "Once you join the streets you will have to do it": sexual practices of street children and youth in Uasin Gishu County, Kenya. Reprod Health. 2015;12:1-11. https://doi.org/10.1186/s12978-015-0090-z\%5Cn.

28. UN. Definition of Youth. Available from: http://www.un.org/esa/socdev/ documents/youth/fact-sheets/youth-definition.pdf.

29. CRA. Kenya County Fact Sheets: Uasin Gishu County. Nairobi: Commision on Revenue Allocation, Government of Kenya; 2011. Available from: http:// siteresources.worldbank.org/INTAFRICA/Resources/257994-1335471959878/ Kenya_County_Fact_Sheets_Dec2011.pdf.

30. Einterz RM, Kimaiyo S, Mengech HNK, Khwa-Otsyula BO, Esamai F, Quigley F, et al. Responding to the HIV pandemic: the power of an academic medical partnership. Acad Med. 2007;82(8):812

31. Ayuku D, Makori D, Sang E, de Long A, Tarus C, Kamanda A, et al. They all count: An adapted Point-in-Time census approach to counting street-connected children and youth in a mid-sized city of western Kenya. under Dev.

32. Helbling J, Kalin W, Nobirabo P. Access to justice, impunity and legal pluralism in Kenya. J Leg Plur Unoff Law. 2015;47:347-67.

33. Phillips-Howard PA, Odhiambo FO, Hamel M, Adazu K, Ackers M, van Eijk AM, et al. Mortality trends from 2003 to 2009 among adolescents and young adults in rural Western Kenya using a health and demographic surveillance system. PLoS One. 2012;7:e47017. Available from: http://www. ncbi.nlm.nih.gov/pubmed/23144796.

34. Nada KH, Suliman el DA. Violence, abuse, alcohol and drug use, and sexual behaviors in street children of greater Cairo and Alexandria, Egypt. AIDS 2010;24(Suppl 2):S39-44. Available from: http://www.ncbi.nIm.nih.gov/ pubmed/20610947.

35. Wachira J, Kamanda A, Embleton L, Naanyu V, Winston SE, Ayuku D, et al. Initiation to street life: a qualitative examination of the physical, social, and psychological practices in becoming an accepted member of the street youth community in western Kenya. BMC Public Health. 2015;20

36. Lockhart C. The life and death of a street boy in East Africa: everyday violence in the time of AIDS. Med Anthropol Q. 2008;22:94-115.

37. Kudrati M, Plummer ML, Yousif ND. Children of the sug: a study of the daily lives of street children in Khartoum, Sudan, with intervention recommendations. Child Abuse Negl. 2008;32:439-48. Available from: http:// www.ncbi.n/m.nih.gov/entrez/query.fcgi?cmd=Retrieve\&db=PubMed\&dopt= Citation\&list_uids=18457872.

38. UNICEF. The state of the World's children 2012: children in an urban world. New York: UNICEF; 2012.

39. Muiruri G. Street children need to be loved, not treated like thugs. Kenya: Stand. Media; 2016. Available from: http://www.standardmedia.co.ke/ureport/ article/2000187001/street-children-need-to-be-loved-not-treated-like-thugs.

40. Barsulai J. Kenya's street children struggle to get accepted. Nairobi: Stand. Media Kenya; 2014. Available from: http://www.standardmedia.co.ke/article/ 2000106736/kenya-s-street-children-struggle-to-get-accepted.

41. Blomfield A. Revealed: how raid by Kenyan police drove street children to their deaths. Eldoret: Guard; 2016. Available from: https://www.theguardian. com/world/2016/oct/10/exposed-kenyan-polices-brutal-attacks-on-streetchildren.

42. National Council for Law Reporting with the Authority of the Attorney General. The Children Act: Chapter 141. Kenya; 2010. Available from: http:// www.kenyalaw.org/lex/rest/db/kenyalex/Kenya/Legislation/English/ Acts\%20and\%20Regulations/C/Children\%20Act\%20Cap.\%20141\%20-\%20No. \%208\%20of\%202001/docs/ChildrenAct8of2001.pdf.
43. Goldblatt A, Kwena Z, Lahiff M, Agot K, Minnis A, Prata N, et al. Prevalence and correlates of HIV infection among street boys in Kisumu, Kenya. PLoS One. 2015;10

44. NACC. Kenya AIDS response progress report: progress towards zero. Nairobi; 2014

45. Wachira J, Ndege S, Koech J, Vreeman RC, Ayuo P, Braitstein P. HIV testing uptake and prevalence among adolescents and adults in a large homebased HIV testing program in western Kenya. J Acquir Immune Defic Syndr. 2014;65:e58-66.

46. NCPD. Kenya adolescent reproductive health and development policy: implementation assessment report. Nairobi; 2013.

47. Godia PM, Olenja JM, Hofman JJ, van den Broek N. Young people's perception of sexual and reproductive health services in Kenya. BMC Health Serv Res. 2014;14:-172. Available from: http://www.pubmedcentral.nih.gov/ articlerender.fcgi?artid=3996312\&tool=pmcentrez\&rendertype=abstract.

48. Godia PM, Olenja JM, Lavussa JA, Quinney D, Hofman JJ, van den Broek N Sexual reproductive health service provision to young people in Kenya; health service providers' experiences. BMC Health Serv Res. 2013;13:-476. Available from: http://www.ncbi.nlm.nih.gov/pubmed/24229365.

49. Sorber R, Winston S, Koech J, Ayuku D, Hu L, Hogan J, et al. Social and economic characteristics of street youth by gender and level of street involvement in Eldoret, Kenya. PLoS One. 2014; in press

50. Embleton L, Ayuku D, Atwoli L, Vreeman R, Braitstein P. Knowledge, attitudes, and substance use practices among street children in western Kenya. Subst Use Misuse. 2012;47:1234-47. Available from: http://www.ncbi. nlm.nih.gov/pubmed/22780841.

51. Embleton L, Atwoli L, Ayuku D, Braitstein P. The journey of addiction: barriers to and facilitators of drug use cessation among street children and youths in western Kenya. PLoS One. 2013;8:e53435. Available from: http:// www.ncbi.nlm.nih.gov/pubmed/23326428.

52. Embleton L, Wachira J, Kamanda A, Naanyu V, Ayuku D, Braitstein P. Eating sweets without the wrapper: perceptions of HIV and sexually transmitted infections among street youth in western Kenya. Cult Health Sex. 2015:1-12.

\section{Ready to submit your research? Choose BMC and benefit from:}

- fast, convenient online submission

- thorough peer review by experienced researchers in your field

- rapid publication on acceptance

- support for research data, including large and complex data types

- gold Open Access which fosters wider collaboration and increased citations

- maximum visibility for your research: over $100 \mathrm{M}$ website views per year

At BMC, research is always in progress.

Learn more biomedcentral.com/submissions 